By the side of this first assemblage of facts, of which the meaning seems to me not doubtful, I find another of at least equal importance-that of meteoric rocks evidently eruptive.

The meteoric iron recently discovered in the cordillera of Deesa, in Chili, having been submitted by me to a careful analysis, both chemical and mineralogical, appeared to me clearly to be formed from the mixture of two meteoric rocks, known, each of them, by masses of which they are entirely constituted. The one, stony and black, fell at Sétif, Algeria (June 9, I867); the other, metallic, constitutes the mass of iron found in 1828 at Caille, in the south of France. Besides this, the metallic portion of the iron of Deesa, in which the black angular fragments are encrusted, has manifestly preserved the character assumed by the iron of Caille when it is subjected to fusion, so that the mode of formation of the Chilian mass cannot be considered doubtful. We must believe that on a globe, large enough to have been the seat of considerable pressure, masses of iron from Caille, still melted, were injected into superposed layers of Sétif rock so as to give birth to clykes, identical, except in their mineralogical nature, with those which the crust of the earth everywhere presents to our view.

These two orders of facts, which seem to me indisputable, being admitted, there remains to explain how fragments of polygenic conglomerates, or of dykes, can wander through space, and here only it is that the hypothetic part of my work begins.

From what precedes the meteorites in question are, by definition, planetary fragments. It remains to learn how the rupture of the planet whence they come can have taken place. On this it is evidently impossible to argue with any certainty.

Nevertheless, it appears to me that several considerations may rreatly facilitate a choice among the different explanations which present themselves to the mind.

In the first place the untity of composition of the solar system, mentioned by Mr. Maskelyne, is evident.

Secondly, it is manifest that in the same system there exists a perfect unity of geological phenonena.

Lastly, but this, perhaps, has less weight, it appears to me that we should have recourse to accidental causes to explain natural phenomena only when every other means is forbidden.

This said, I observe that without making any other hypothesis than that of Laplace, we arrive at the conclusion that the stars tend of themselves to become broken. The earth is cracked in all directions; these fissures, designated as faults, are known to everyone. Little by little, as they form, they become reunited by the injection of an internal melted cement. But if the supply of this cement failed, the molecular operation which has opened the faults would still continue its action to enlarge them; we observe this in the moon, which, far more advanced in refrigeration, manifests by its fissures a phenomenon hitherto unknown in our earth. Evidently if we suppose to have been formed at the same time as the moon, a much smaller globe, that globe will have arrived actually at a state of cold far more advanced than that of the moon; and the fissures, excessively multiplied, and increased in depth and in width, may have finished by reducing the globe into separate fragments.

We have no positive proofs that such events have really happened, but is it not a very simple hypothesis to admit that meteorites, which bear so evidently the impress of a detritic character, may have had such an origin?

It is very probable that once parted from one another, the fragments are scattered along the orbit, and it is evident that they will tend progressively to approach the central star, so as to finish by falling on its surface under the form of meteorites.

Now, whether these fragments have been sorted or whether they have not, whether this sorting, if it exists, be or be not in accordance with that which the facts of observation have seemed to point out to me ; I consider the question as entirely secondary as regards the general theory, and I request permission, in order to keep within the limits of the present discussion, to lay it absolutely aside for the present. I will simply repeat, in concluding this note, already somewhat long, that positive facts alone have served as the basis of my theory, and that the different circumstances on which my opponent has so learnedly insisted, possess for me but a secondary importance.

At the same time, I sincerely congratulate myself in the fact that my work has had the good fortune to fix the attention of a scientific observer so well placed as Mr. Maskelyne for submitting the mincralogical and lithological part of it to a severe verification.

Dr. STanislas MEUnicr, Aide Naturaliste au Muséum 23, rue de Vaugirard, à Paris

\section{Monographs of M. Michel Chasles}

Par une lettre inséréee dans le No. 36 de Nature, page 190, M. C. Ingleby fait appel aux lecteurs de votre Revue pour obtenir quelques renseignements au sujet de "l'Aperçu historique" de $M$. Chasles, imprimé à Bruxelles en I837. Le travail, qui porte pour titre exact : "Aperçu historique sur l'origine et le développement des méthodes en géométrie, particulièrement de celles qui se rapportent a la géométrie moderne," a été publié par l'Académie royale des sciences de Belgique dans le tome xi. de ses "Mémoires couronnés et des savants étrangers" (in 4to.) et il est très-difficile aujourd'hui de s'en procurer des exemplaires. Toutefois, M. Ingleby pourra s'adresser, pour consulter ce mémoire, à la Société royale de Londres, qui doit certainement le posséder dans sa Bibliothéque. Voici d'ailleurs la liste des établissements scientifiques de Londres qui ont reçu cet ouvrage a l'époque de sa publication: Société royale, Société astronomique, Société royale de littérature, et Société limnéenne.

J'espère que ces details pourront être utiles à votre honorable correspondant.

\section{Bruxelles, le 8 Juillet}

A. LANCASTER, Attaché au Secrétariat de l'Académie royale des Sciences de Belgique

IN reply to Dr. Ingleby's note I may state that many papers by M. Chasles on varicus subjects in the history of Mathematics, are to be found in the volumes of the Comptes Rendus for 1837 , onwards. His "Aperçu Historique" \&c., originally appeared as a special volume of the Transactions of the Brussels Academy, but was sold as an independent work. It appeared in quarto, and was published in 1837. Like his "Traité de Géométrie Supérieure," it is very rare, and fetches an enormous price. Mr. Quaritch is, perhaps, the most likely bookseller in London to be able to procure it. The German translation by Sohncke is comparatively cheap, and may be readily obtained through Messrs. Williams and Norgate.

Torquay, July 9

G. E. DAY

\section{The Specific Heat of Mixtures of Alcohol and Water}

IN the report of the papers read at the Academy of Sciences, Paris, June 13, which appears in NATURE for June 30 , it is stated that MM. Jamin and Amaury presented a note on the above subject, in which they point out, apparently as if it were something new, that the specific heat of some of these mixtures rises even above that of water.

Now, more than two years ago, March 26, I868, we communicated a paper to the Royal Society giving the specific heat of various mixtures of alcohol and water, and drawing special attention to the remarkable fact that the specific heat of these mixtures is not only above the calculated mean specific heat, but that in all those of less strength than 36 per cent. of alcohol, it is higher than the specific heat of water itself. A knowledge of this fact should therefore be old by this time.

An abstract of our paper is printed in Proc. R. S., vol. xvi., p. 337. Subsequently we examined this and various other properties of similar mixtures more in detail, and communicated our results to the Royal Society in a second paper, an abstract of which is printed in Proc. R.S., vol. xvii., p. 333, and the paper in full in Phil. Trans. for 1869 , Part II., p. $59 \mathrm{I}$.

The insertion of the above in the next number of your valuable journal will greatly oblige

Westminster Hospital, July 2

\section{Geographical Prizes}

HAVING been chiefly instrumental in causing prize medals to be offered by the Geographical Society for competition among the chief public schools, I do not like Mr. Wilson's letter in your last number to pass without comment.

Geography may be, to use his words, a subordinate branch of education, but I maintain that it is so only in the sense that it underlies a large part of liberal knowledge. It underlies the study of history. For example, I do not see how a boy could thoroughly understand Biblehistory without having acquired a very vivid conception of the geography of Palestine, and the same is true for all other histories, ancient and modern. It follows, as a matter of fact, that geography is incidentally taught to a considerable extent in schools, and I am sorry to say it is sometimes very ill-taught, as we learn from the reports of our examiners, but 